Lynch, P.B. 1966. Conduct of Field Experiments. Bulletin No. 399. New Zealand Department of Agriculture

Ministry for Primary Industries. 2013. Nutrien Management Science - State of Knowledge, Use an Uptake in New Zealand. MPI Technical Paper No 2013/59.

Our Nutrient World. 2013. The Challenge to Produce More Food and Energy with Less pollution. Accessed: 17/4/2015. http://www.initrogen.org/publ_panel
Roberts, A.; Morton, J. 2004. Fertiliser use on New Zealand dairy farms. New Zealand Fertiliser Manufacturer's Research Association. Auckland, New Zealand.

Shepherd, M.; Lucci, G. 2013. A review of the effect of autumn nitrogen fertiliser on pasture nitrogen concentration and an assessment of the potential effects on nitrate leaching risk. Proceedings of the New Zealand Grassland Association 75: 197-202.

\section{Response of pastures to fertiliser nitrogen on two peat soils in the Waikato region}

W.T. CARLSON, G.L. LUCCI and M.S. SPROSEN AgResearch Ruakura, Private Bag 3123, Hamilton 3240, New Zealand

\section{Abstract}

Fertiliser nitrogen $(\mathrm{N})$ response trials were conducted on Waikato dairy pastures on two contrasting peat soils: a well-developed Kaipaki peat loam and a lessdeveloped Rukuhia peat. On the well-developed site the most efficient $\mathrm{N}$ fertiliser rate in spring was $25 \mathrm{~kg} \mathrm{~N} /$ ha with a response of $22 \mathrm{DM} / \mathrm{kg} \mathrm{N}$ applied. However, in autumn the most efficient rates of $\mathrm{N}$ fertiliser were 75 and $100 \mathrm{~kg} \mathrm{~N} / \mathrm{ha}$, with an average response rate of $11 \mathrm{~kg} \mathrm{DM} / \mathrm{kg} \mathrm{N}$. At the less-developed site, the most efficient rates in the spring were 25 to $75 \mathrm{~kg} \mathrm{~N} / \mathrm{ha}$ with an average response of $18 \mathrm{DM} / \mathrm{kg} \mathrm{N}$ applied. In autumn, the maximum response rate of $21 \mathrm{~kg} \mathrm{DM} / \mathrm{kg} \mathrm{N}$ was reached through application of 50 and $75 \mathrm{~kg} \mathrm{~N} / \mathrm{ha}$. Results indicate that greater yields are expected from larger applications of $\mathrm{N}$ fertiliser on less-developed peat. However, the environmental consequences of increased $\mathrm{N}$ fertiliser applications have not yet been assessed.

Keywords: nitrogen fertiliser, pasture production, peat

\section{Introduction}

There are around 94000 ha of peat (organic) soils in the Waikato with $80 \%$ of the area developed fo agriculture (O'Connor et al. 2001). The properties of peat soils (e.g. carbon content, $\mathrm{pH}$, and water holding capacity) change with development stage from raw to consolidated forms due to drainage and cultivation; developed peat has a higher bik densty cons organic matter and al. 2006), OConnor etal. (2001) used the development state of organic soils to develop guidelines for fertiliser applications of phosphate, potassium and sulphur. However, there have been few studies in New Zealand on the response of pastures on peat soils to $\mathrm{N}$ fertiliser, and in particular how the stage of development might affect response (van der Elst 1980; Baars et al. 1989) values in mineral soils explain some of the variation in pasture response to $\mathrm{N}$ fertiliser (Shepherd et al. 2015), but it is unclear if this relationship holds for peat soils. Spring and autumn field studies on two peat soils of differing development status were commenced in August 2015. The objective was to determine which rates of $\mathrm{N}$ fertiliser produced the most efficient pasture response on peat soils.

\section{Methods}

\section{Trial location}

The two experimental sites in the Waikato region, north of Hamilton, were selected to represent contrasting pea soils used for dairy farming. The well-developed (WD) site was on a Kaipaki peat in an area that was developed for farming in the 1890s. The soil had a high anion storage capacity (ASC) and Olsen P status (Table 1). The less-developed (LD) site was on a Rukuhia peat, in Canded for farming in the 197 ASC and a moderate P status (Table 1). Both sites were on well established, intensively grazed ryegrass/white clover pastures with low bulk density and high total carbon, compared with mineral soils. Before the start of the trial, soil measurements were taken to characterise the sites (Table 1).

\section{Trial design and management}

The experimental design at both sites and seasons consisted of: 5 treatments $\mathrm{x} 5$ replicates arranged in a andomised block design. The treatments were: 0,25 , 50,75 and $100 \mathrm{~kg} \mathrm{~N} / \mathrm{ha}$, applied as granular urea to 1.5 $\mathrm{x} 4 \mathrm{~m}$ plots. A single urea application was followed by 3 pasture harvests. The spring and autumn trials were in separate nearby areas.

Basal fertiliser was applied to both spring and autumn

Table 1 Soil properties of the 2 sites $(0-15 \mathrm{~cm}$ depth). Samples were analysed for $\mathrm{pH}$, Olsen phosphorus (P), potassium (K) sulphur (S), anion storage capacity (ASC), total nitrogen (TN), total carbon (TC) and bulk density (BD).

\begin{tabular}{|c|c|c|c|c|c|c|c|c|c|}
\hline \multirow[t]{2}{*}{ Site } & \multirow[t]{2}{*}{$\mathrm{pH}$} & \multirow{2}{*}{$\begin{array}{c}\mathbf{P} \\
(\mu \mathrm{g} / \mathrm{ml})\end{array}$} & \multirow{2}{*}{$\begin{array}{c}\mathbf{K} \\
\text { (QT) }\end{array}$} & \multirow{2}{*}{$\begin{array}{l}\mathbf{S}\left(\mathrm{SO}_{4}\right) \\
(\mathrm{ppm})\end{array}$} & ASC & TN & TC & \multirow{2}{*}{$\begin{array}{l}\text { C:N } \\
\text { ratio }\end{array}$} & \multirow{2}{*}{$\begin{array}{c}\text { BD } \\
\mathrm{g} / \mathrm{cm}^{3}\end{array}$} \\
\hline & & & & & & (\%) & & & \\
\hline LD & 5.4 & 24 & 5 & 6 & 19 & 1.67 & 37.1 & 22 & 0.37 \\
\hline WD & 5.7 & 63 & 2 & 25 & 96 & 1.11 & 20.9 & 19 & 0.51 \\
\hline
\end{tabular}


trial sites before urea application to ensure that there were no nutrient deficiencies limiting pasture growth Additional applications of potassium and sulphur fertiliser were applied during the trial to compensate for nutrient removal in pasture harvests. Pasture was cut to a $5 \mathrm{~cm}$ stubble with a motor mower, and all clippings were weighed; a subsample was taken for dry matter $(\%$ DM) determination. The clippings were removed from the site.

\section{Statistical analysis}

Analysis of variance (ANOVA) (GENSTAT v 17.1) was used to compare means of treatments.

\section{Results and Discussion}

Spring application pasture DM response to $\mathrm{N}$ fertiliser

In the spring, the average growth period was 21 days. The combined base DM harvest (nil fertiliser $\mathrm{N}$ applied) on the WD site was $3707 \mathrm{~kg} \mathrm{DM} / \mathrm{ha}$ for three harvests. Three base DM harvests from the LD site yielded 1469 $\mathrm{kg} \mathrm{DM} / \mathrm{ha}$, or $40 \%$ of that of the WD soil, indicating a difference in the potential production between sites (Table 2). This underlying difference could not be removed completely by the addition of fertiliser $\mathrm{N}$.

There was a significant increase $(\mathrm{P}<0.005)$ in pasture harvested from the WD site after the $25 \mathrm{~kg} \mathrm{~N} / \mathrm{ha}$ application, but higher rates of fertiliser $\mathrm{N}$ did not result in significant increases in pasture growth. At the second harvest, only the two higher $\mathrm{N}$ rates (75 and $100 \mathrm{~kg}$ $\mathrm{N}$ ) had significantly more growth than the control. By the third harvest, the effects of $\mathrm{N}$ fertiliser on pasture growth had disappeared (Table 2).

The first and second harvests from the LD site showed a near-linear response to increasing $\mathrm{N}$ fertilise

Table 2 Average harvested dry matter $(\mathrm{kg} \mathrm{DM} / \mathrm{ha}$ ) from spring applications of nitrogen $(\mathrm{N})$ fertiliser. Cumulative rainfall during the growth periods is also presented. The LSD is the least significant difference in harvested DM between treatments $(\mathrm{P}<0.05)$

\begin{tabular}{|c|c|c|c|c|c|c|c|}
\hline \multicolumn{8}{|c|}{ Fertiliser treatment $(\mathrm{kg} \mathrm{N} / \mathrm{ha})$} \\
\hline Site, harvest dates and number of days (d) & 0 & 25 & 50 & 75 & 100 & LSD $_{5 \%}$ & Rain (mm) \\
\hline \multicolumn{8}{|l|}{ WD } \\
\hline $30 / 9$ (21 d) & 1068 & 1473 & 1612 & 1686 & 1738 & 168 & 75 \\
\hline $21 / 10(21 \mathrm{~d})$ & 1573 & 1723 & 1737 & 1843 & 1936 & 209 & 42 \\
\hline Total harvest 1 and 2 & 2641 & 3196 & 3349 & 3529 & 3674 & 319 & 117 \\
\hline 19/11 (29 d) & 1066 & 1068 & 872 & 790 & 898 & 186 & 58 \\
\hline \multicolumn{8}{|l|}{ LD } \\
\hline $14 / 10(23 d)$ & 674 & 970 & 1295 & 1571 & 1626 & 195 & 60 \\
\hline $5 / 11(22 \mathrm{~d})$ & 324 & 498 & 617 & 760 & 917 & 71 & 42 \\
\hline Total harvest 1 and 2 & 998 & 1468 & 1912 & 2331 & 2543 & 243 & 102 \\
\hline $30 / 11(25 d)$ & 471 & 431 & 375 & 361 & 365 & 95 & 100 \\
\hline
\end{tabular}

\& Field 1982; Shepherd et al. 2015). In spring on the LD site, an additional $18 \mathrm{~kg}$ $\mathrm{DM} / \mathrm{kg} \mathrm{N}$ was grown where the application rate of 25 $\mathrm{kg} \mathrm{N} / \mathrm{ha}$ was used. Pasture responses to fertiliser $\mathrm{N}$ remained relatively high at the rates of $\mathrm{N}$ applied above $25 \mathrm{~kg} \mathrm{~N} / \mathrm{ha}$ (Figure 1). This $25 \mathrm{~kg} \mathrm{~N} /$ ha (Figure 1). This
response would suggest a response would suggest a
substantial $N$ limitation at substantia
this site.

In the autumn trial on the WD site for the application rate of $25 \mathrm{~kg} \mathrm{~N} / \mathrm{ha}$ an additional $2.7 \mathrm{~kg} \mathrm{DM} / \mathrm{kg}$ $\mathrm{N}$ was grown. Pasture responses to fertiliser $\mathrm{N}$ increased with increasing rates of $\mathrm{N}$ applied above 25 $\mathrm{kg} \mathrm{N} / \mathrm{ha}$. Overall, response to $\mathrm{N}$ fertiliser was greater at the LD site, with an response of $21 \mathrm{~kg} \mathrm{DM} / \mathrm{kg} \mathrm{N}$ meas

$\mathrm{kg} \mathrm{N}$ treatments over three harvests. These rates between these two sites in fertiliser $\mathrm{N}$ As there was only one example of each devc tage, it is not poss stage, it is no pos the development status is the only reason for differences eneen the sites, pasture age and composition, and paddock history would all have had an effect on pasture growth measured. However, previous research (van der Elst 1980; O'Connor et al. 2001; Simmonds et al. 2015) Pasture yields $(\mathrm{kg} D \mathrm{DM} / \mathrm{ha})$ in response to different rates of autumn-applied $\mathrm{N}$ fertiliser. Cumulative rainfall during the
periods is also provided. The LSD is the least significant difference in harvested DM between treatments $(P<0.05)$.

\begin{tabular}{|c|c|c|c|c|c|c|c|}
\hline \multicolumn{8}{|c|}{ Fertiliser treatment (kg N/ha) } \\
\hline Site, harvest dates and number of days (d) & 0 & 25 & 50 & 75 & 100 & $\mathrm{LSD}_{5 \%}$ & Rain $(\mathrm{mm})$ \\
\hline \multicolumn{8}{|l|}{ WD } \\
\hline $10 / 5(35 d)$ & 246 & 330 & 349 & 394 & 416 & 66 & 30 \\
\hline $4 / 7(55 \mathrm{~d})$ & 940 & 1001 & 1106 & 1356 & 1567 & 270 & 298 \\
\hline 29/8 (57d) & 1214 & 1137 & 1110 & 1457 & 1559 & 193 & 244 \\
\hline Total harvest 1,2 and 3 & 2400 & 2468 & 2565 & 3207 & 3542 & 448 & 572 \\
\hline \multicolumn{8}{|l|}{ LD } \\
\hline $9 / 5(36 d)$ & 147 & 247 & 425 & 486 & 523 & 89 & 32 \\
\hline $11 / 7(63 \mathrm{~d})$ & 244 & 398 & 702 & 1022 & 1076 & 237 & 318 \\
\hline $14 / 9(66 \mathrm{~d})$ & 441 & 590 & 748 & 899 & 970 & 182 & 253 \\
\hline Total harvest 1,2 and 3 & 832 & 1235 & 1875 & 2407 & 2569 & 458 & 603 \\
\hline
\end{tabular}


release of $\mathrm{N}$ from the organic soils. The $\mathrm{C}: \mathrm{N}$ ratio was slightly higher in LD, and the low base growth and high response to $\mathrm{N}$ fertiliser is evidence of N limitation. However, it does not appear that the slight difference in C: $\mathrm{N}$ could fully explain the differences in $\mathrm{N}$ response between the two sites.

\section{Conclusions}

These findings indicate that farmers on less developed peat have lower base growth but can expect greater yield benefits from larger applications of $\mathrm{N}$ fertiliser Farms with WD soils, similar to those here, can expect efficient pasture yield increases in the spring from rates of $25 \mathrm{~kg} \mathrm{~N} / \mathrm{ha}$. It should be noted that the environmenta consequences of increased applications of $\mathrm{N}$ fertiliser have not been assessed in this study.

\section{AKNOWLEDGEMENTS}

This project has been funded by the Ministry for Primary Industries through the Sustainable Farming Fund (project \# 408101), and by Ballance AgriNutrients, Waikato Regional Council and New Zealand dairy farmers through DairyNZ. The authors would also like to thank Harry Rich of Orini, and Brett and Rache Gordon of Eureka for their cooperation, engagemen and use of their properties for these experiments.

\section{REFERENCES}

Baars, J.A.; O'Conner, M.B.; Ledgard, S.F.; Wallace, R.D. 1989. Nitrogen fertiliser use in intensive bull beef production on peat soils in the Waikato. pp. 28 36. In: Nitrogen in New Zealand Agriculture an Horticulture. Eds. White R.E.; Currie L.D. Occasional Report No 3, Fertiliser and Lime Research Centre, Massey University.
Ball, P.R.; Field, T.R.O. 1982. Responses to nitrogen as affected by pasture characteristics, season, and grazing management. pp. 45-64. In: Nitrogen fertilisers in New Zealand agriculture. Ed. Lynch, P.B. New Zealand Institute of Agricultural Science, Wellington.

Holden, J.; Evans, M.G.; Burt, T.P.; Horton, M. 2006. Impact of land drainage on peatland hydrology. Journal of Environmental Quality 35: 1764-1778.

Kelliher, F.M.; van Koten, C.; Lindsey, S.B.; Wise, B.; Rys, G. 2016. Nitrous oxide emissions from drained peat soil beneath pasture. New Zealand Journal of Agricultural Research 59: 363-376.

Nieveen, J.P.; Campbell, D.I.; Schipper, L.A.; Blair, I.J. 2005. Carbon exchange of grazed pasture on a drained peat soil. Global Change Biology 11: 607618.

O’Connor, M.B.; Longhurst, R.D.; Johnston, T.J.M.; Portegys, F.N. 2001. Fertiliser requirements for peat Zealand Grassland Association 63: 47-51.

chipper, L.A.; McLeod, M. 2002. Subsidence rates and carbon loss in peat soils following conversion to pasture in the Waikato Region, New Zealand. Soil Use and Management 18: 91-93.

Shepherd, M.; Ghani, A.; Rajendram, G.; Carlson, B.; Pirie, M. 2015. Soil total nitrogen concentration explains variation in pasture response to spring nitrogen fertiliser across a single farm. Nutrient Cycling in Agroecosystems 101: 377-390.

an der Elst, F.H. 1980. Development of peat soils for agriculture. Chapter 4. In: Soil Groups of New Zealand, Part 4, Organic Soils. Eds. van der Elst, F.H.; Kinloch, D. New Zealand Society of Soil Science. Wellington, New Zealand.

\section{Soil inorganic nitrogen in spatially distinct areas within a commercial dairy farm in Canterbury, New Zealand}

D.C. EKANAYAKE ${ }^{1}$, J.L. OWENS ${ }^{2}$, S. HODGE ${ }^{2}$, J.A.K. TRETHEWAY' ${ }^{1}$, R.L. ROTEN ${ }^{1}$, M. WESTERSCHULTE ${ }^{1}$, S.BELIN ${ }^{1}$, A. WERNER ${ }^{1}$ and K. CAMERON ${ }^{1}$ Lincoln Agritech Ltd., PO Box 69 133, Lincoln, Canterbury 7640, New Zealand ${ }_{2}^{2}$ Agriculture and Life Sciences Faculty, PO Box 84, Lincoln University, Lincoln, New Zealand dinanjana.ekanayake@lincolnagritech.co.nz

\section{Abstract}

For precision nitrogen $(\mathrm{N})$ fertilisation of grazed dairy paddocks, soil $\mathrm{N}$ distribution needs to be quantified. It is expected that farm infrastructure will affect inorganic- $\mathrm{N}$ distribution due to its influence on cow grazing behaviour. Surface soil from four spatially distinct areas (main gate, water troughs, non-irrigated and the remaining pasture) was analysed for soil ammonium- $\mathrm{N}$ $\left(\mathrm{NH}_{4}^{+}-\mathrm{N}\right)$ and nitrate- $\mathrm{N}\left(\mathrm{NO}_{3}{ }^{-} \mathrm{N}\right)$ from three paddocks (180 soil samples) on an irrigated commercial dairy farm in Canterbury, New Zealand. Variation between paddocks was higher for $\mathrm{NO}_{3}^{-}(\mathrm{P}<0.001)$ than for $\mathrm{NH}_{4}^{+}(\mathrm{P}=0.52)$. Differences between spatially distinct areas were detected for $\mathrm{NH}_{4}^{+}(\mathrm{P}<0.001)$ but not for $\mathrm{NO}_{3}^{-}(\mathrm{P}=0.37)$, though there was variation in $\mathrm{NO}_{3}$ with distance from the gates and troughs. This study demonstrates methods for classifying spatially distinct areas of grazed pasture to quantify their influence on inorganic-N distribution. Further research is required to better understand variability.

Keywords: nitrogen, spatial nitrogen distribution, distinct areas

\section{Introduction}

Use of centre pivot irrigation and repetitive mineral $\mathrm{N}$ fertiliser applications on grazed paddocks have increased to support the intensification of dairy production in New Zealand (Foote et al. 2015). Precision fertilisation can exclude high $\mathrm{N}$ areas, reduce fertiliser amounts without sacrificing yields (Diacono et al. 2013), and reduce $\mathrm{NO}_{3}^{-}$leaching (Foote et al. 2015). Strategies for precision fertilisation within cattle-grazed paddocks differ from cropped areas due to heterogeneous grazing behaviours of cattle (Sanderson et al. 2010).

Cattle grazing patterns are spatially uneven, as cows can spend $\sim 50 \%$ of their time within $13 \%$ of the paddock (Hunt et al. 2007). Repeated grazing results in spatially random excreta distribution in the paddock (White et al. 2001), and rates of soil $\mathrm{N}$ accumulation are affected by stocking rate, grazing intensity and rotation (White et al. 2001; Hunt et al. 2007; Putfarken et al. 2008). However, cattle are known to frequent reas around farm infrastructure like water troughs, ences and shelter belts (White et al. 2001; Hunt et al. 2007; Putfarken et al. 2008), which may result in higher soil $\mathrm{N}$ in these areas. Identifying spatially distinct areas based on the orientation of farm infrastructures (i.e. water troughs, fences, shelter belts), may provide a way to characterise spatial $\mathrm{N}$ distribution around a grazed dairy pasture.

A strategy is needed to quantify the spatial distribution of $\mathrm{N}$ within intensively grazed pastures and to related farm infrastructure to develop precision ertiliser schemes. The objective of this paper was to test a methodology to delineate farm infrastructure related spatially distinct areas around a typical New Zealand dairy farm, and to quantify spatial distribution of $\mathrm{NH}_{4}^{+}-\mathrm{N}$ and $\mathrm{NO}_{3}^{-}-\mathrm{N}$.

\section{Materials and methods}

\section{Experimental site}

The site was an irrigated commercial dairy farm in Rolleston $\left(43.56750^{\circ} \mathrm{S}, 172.32334^{\circ} \mathrm{E}\right)$, Canterbury, New Zealand. The soil was a stoneless, free-draining Lismore silt loam (Pallic Firm Brown Soil, Hewitt 2010). The farm stocking density was 3.6 cows/ha for a herd of 630 Friesians. Cows were rotationally grazed on perennial ryegrass (Lolium perenne)/ white (Len The days for March, April and May, respectively, during 2017) with supplementary feed provided as required. Tota broadcast N-fertiliser was $190 \mathrm{~kg} \mathrm{~N} / \mathrm{ha}$ from September 2016 to April 2017, including $50 \mathrm{~kg} / \mathrm{ha}$ of 'SustaiN $25 \mathrm{~K}$ ' (at $23 \% \mathrm{~N}$ ) fertiliser after each grazing. Pasture irrigation averaged $3 \mathrm{~mm} / \mathrm{ha} /$ day from October 2016 to March 2017.

\section{Soil Sampling}

Three paddocks (coded 17, 19 and 33), each 5.1-5.5 ha and located in the centre pivot irrigation area, were selected for soil sampling. Each paddock included main gate, a water trough, and low producing (nonirrigated) area, that were spatially distinct.

Different sampling regimes were used for each distinct area of the paddock to obtain spatially 